\title{
THERMODYNAMIC STUDY ON VAPOUR-LIQUID EQUILIBRIUM OF TOLUENE and SEVERAL TYPES OF OIL AS ABSORBENT
}

\author{
Hendriyana*1, Suhartono ${ }^{2}$, and Herri Susanto ${ }^{2}$ \\ ${ }^{1}$ Chemical Engineering Department, Universitas Jendral Ahmad Yani \\ Jalan Terusan Jenderal Sudirman PO BOX 148 Cimahi \\ ${ }^{2}$ Chemical Engineering Study Program, Faculty of Industrial Technology \\ Institut Teknologi Bandung, Jalan Ganesha 10 Bandung, 40132 \\ Email: yana_hendri2001@yahoo.com
}

\begin{abstract}
Gas cleaning system is one of important step in the utilization of biomass via gasification process. The producer gas obtained from the gasification process must be very clean before it is used in an internal combustion engine. In order to gaseous fuel get cleaned with a tar content below $100 \mathrm{mg} / \mathrm{Nm}^{3}$, a gas cleaning system using scrubbing oil is being developed and taking the advantage of a lower vapour pressure of oil than scrubbing water. Study on vapour-liquid equilibrium is being conducted to understand the phenomena taking place in the absorption of tar with oil. In our present study, the producer gas containing tar is representated using air containing toluene. This producer gas model with a toluene or benzene concentration then bubbled with a rate of $27.6 \mathrm{~mL} / \mathrm{min}$ into a bath of oil at a various temperature. The progress of absorption of tar model in oil measured gas cromathograpy until saturated condition. Considering that the concentration of toluene in the gas stream is very low, the toluene and oil vapour-liquid equilibrium follows the Henry's law. Prediction of Henry's constants is also carried out using UNIFAC-FV model which is known to be suitable for hydrocarbon gases and high-boiling point hydrocarbon solvent.
\end{abstract}

Keywords: tar, oil, Henry's constant

\begin{abstract}
Abstrak
Sistem pembersihan gas merupakan salah satu langkah penting dalam pemanfaatan biomassa melalui proses gasifikasi. Gas produser yang dihasilkan dari proses gasifikasi harus sangat bersih sebelum digunakan dalam mesin pembakaran internal. Untuk mendapatkan bahan bakar gas yang bersih dengan kandungan tar di bawah $100 \mathrm{mg} / \mathrm{Nm}^{3}$. Sebuah sistem pembersihan gas dengan menggunakan minyak sebagai media penyerap dikembangkan dengan mengambil keuntungan dari tekanan uap minyak lebih rendah air penyerap. Studi kesetimbangan uap-cair yang dilakukan untuk memahami fenomena yang terjadi dalam penyerapan tar dengan minyak. Dalam kami studi ini, gas produser yang mengandung direpresentasikan dengan udara yang mengandung toluena. Model gas produser ini dibuat dengan menggelembungkan konsentrasi benzena atau toluena dengan laju 27,6 $\mathrm{mL} / \mathrm{menit}$ ke dalam bak minyak pada berbagai suhu. Kemajuan penyerapan model tar dalam minyak diukur dengan cromathograpy gas sampai dengan kondisi jenuh. Mengingat konsentrasi toluena dalam aliran gas sangat rendah, maka kesetimbangan uap-cair toluena dan minyak mengikuti hukum Henry. Konstanta Henry juga dapat diprediksi dengan menggunakan model UNIFAC-FV yang cocok untuk gas hidrokarbon dan pelarut hidrokarbon dengan titik didih tinggi.
\end{abstract}

Kata kunci: tar, minyak, konstanta Henry

*corresponding author 


\section{Introduction}

Producer gas from biomass gasification contains particulates and tars (volatile organic matters) which may cause severe operational problems. In application of producer gas with an internal combustion engine, high concentrations of particulates and tars can damage the engine and lead to an unacceptable level of maintenance. A gas cleaning system is therefore an important part in an integration of gasification unit with IC engine. Cleaned gaseous fuel for IC-enginer must have particulate and tars content of less than $50 \mathrm{mg} / \mathrm{Nm}^{3}$ and $100 \mathrm{mg} / \mathrm{Nm}^{3}$ respectively (Hasler and Nussbaumer, 1999).

Tars actually composes of various types of compounds having complex physical and chemical properties. A part of tars condens in the upstream of the gas cleaning system at a temperature above $250{ }^{\circ} \mathrm{C}$ and it may easily be scrubbed out from the gas stream using water, but another part of tars with low boiling point usually escapes from a conventional gas cleaning system. Although its concentration is relatively low, the presence of this low boiling point of tars in the gaseous fuel may cause a serious maintenance problem in IC-engine, so finding an appropiate solvent in terms of: absorption capacity, mass transfer rate, recycling possibility and cost is an important task in the development of a producer gas cleaning system.

Experimental and theoretical studies on the absorption of tars using organic solvents are being conducted in our laboratory. In these studies, low boling point tars is represented using toluene. While producer gas are modeled using ambient air. The solvents chosen for this study were type oil that will be a suitable solvent to scrub-out the low boiling point tars in the producer gas. In our experimental works was used a bubbling method with a simple apparatus and a range of partial pressures of tars model compounds, as reported in experimental.

In this paper, we report our theoretical study to predict the absorption capacity of interesting solvents based on the solubility of gas in an inifinite dillusion. In this case, the absorption capacity is representated using Henry's constant which may be predicted using a thermodynamic method.

\section{Thermodynamic Background}

Solubility as a fundamental factor in the absorption capacity of oil for low boiling point tars has been studied extensively for various volatile organic matters. Solubility of gas in liquid may be expressed as follows (Iwai et al., 1981):

$$
\mathrm{y}_{\mathrm{i}} \cdot \mathrm{P}=H \cdot \mathrm{w}_{\mathrm{i}}
$$

Since effect of the pressure on Henry's constant is negligible at low pressures of less than $2 \mathrm{~atm}$. The dimensionless constant $H$ defined by M.-D. Vuong, et al. (2009) with following equation:

$$
\mathrm{C}_{\mathrm{i}, \mathrm{G}}=H^{*} \cdot \mathrm{C}_{\mathrm{i}, \mathrm{L}}
$$

In both equations, Henry's constant can be caculated from the measurements on mol fraction of solute in the gas phase $\left(y_{i}\right)$, total pressure $(\mathrm{P})$, weight fraction of solute in liquid phase $\left(\mathrm{w}_{\mathrm{i}}\right)$, molar concentration of solute in gas and liquid phase $\left(\mathrm{C}_{\mathrm{i}, \mathrm{G}}\right.$ and $\mathrm{C}_{\mathrm{i}, \mathrm{L}}$ respectively), all at the equillibrium conditions. Typical values of Henry's constant for toluene in several solvents are presented in table 1 . The higher $1 / \mathrm{H}^{*}$ (dimensionlles) or the lower $H$ (weight-fraction Henry's constant, Equation 1) is the more soluble toluene in the respective solvents.

\section{Methodology}

\section{UNIFAC FV}

A number of empirical approaches to the estimation of $H$ at low pressure are available using group/bond contribution or structural parameters. Promising methods for correlation at ambient condition are those making use of the above relationships for activity or fugacity coefficients for dilute aqueous dilution. Limiting activity coefficients are popular in engineering applications and lead directly to $H$ after a

Table 1 Henry's constant of toluene in four solvents (Vuong et al., 2009)

\begin{tabular}{lrc}
\hline \multicolumn{1}{c}{ Solvent } & $1 / H^{*}$ (dimensionless) & $H$ (atm/weight frac.) \\
& Equation 2 & Equation 1 \\
\hline di-(2-ethyl)hexyladipate (DEHA) & 2821 & 0.0794 \\
n-Heksadecane & 990 & 0.1894 \\
Oleyl alcohol (70\%) & 1637 & 0.1324 \\
Water & 4 & 60.8695 \\
\hline
\end{tabular}


combination with vapor pressure. The weight-fraction Henry's constant, $H_{1}$, can be given thermodynamically by:

$$
H_{1}=\gamma_{1}^{\infty} \frac{M_{2}}{M_{1}} f_{1}^{o L}
$$

with $\gamma_{1}^{\infty}$ is the activity coefficient at infinite dilution, $M_{1}$ and $M_{2}$ are the molecular weights, and $f_{1}{ }^{o L}$ is the fugacity of pure solute in the liquid state. The activity coefficient at infinite dilution can be estimated based on the UNIFAC-FV model and presented in the following expression of the weight-fraction Henry's constant (Iwai et al.,1981):

$$
\begin{gathered}
\ln H_{1}=\ln f_{1}^{o L}+\ln \frac{r_{1}^{\prime}}{r_{2}^{\prime}}+1+\frac{z}{2} M_{1} q_{1}^{\prime} \ln \frac{r_{2}^{\prime} q_{1}^{\prime}}{r_{1}^{\prime} q_{2}^{\prime}} \\
-\frac{z}{2} M_{1} q_{1}^{\prime}\left(1-\frac{r_{1}^{\prime} q_{2}^{\prime}}{r_{2}^{\prime} q_{1}^{\prime}}\right)+ \\
3 C_{1} \ln \left[\left(\bar{v}_{1}^{\frac{1}{3}}-1\right) /\left(\bar{v}_{2}^{\frac{1}{3}}-1\right)\right]-c_{i}\left(\frac{\bar{v}_{1}}{\bar{v}_{2}}-1\right)(1- \\
\left.\frac{1}{\frac{1}{\bar{v}_{1}^{3}}}\right)^{-1}+\sum_{k} v_{k}^{(i)} *\left(\ln \Gamma_{k}^{(m)}-\ln \Gamma_{k}^{(i)}\right)
\end{gathered}
$$

Parameters $r_{i}^{\prime}$ and $q_{i}^{\prime}$ are relative molecular volume and surface area respectively. They can calculated using the following equation from the sum of molar

\begin{tabular}{|c|c|c|c|c|}
\hline $\begin{array}{l}\text { Main } \\
\text { grup }\end{array}$ & Subgrup & $\boldsymbol{k}$ & $\boldsymbol{R}_{\boldsymbol{k}}$ & $Q_{k}$ \\
\hline \multirow[t]{4}{*}{$1 \mathrm{CH}_{2}$} & $\mathrm{CH}_{3}$ & 1 & 0.9011 & 0.848 \\
\hline & $\mathrm{CH}_{2}$ & 2 & 0.6744 & 0.540 \\
\hline & $\mathrm{CH}$ & 3 & 0.4469 & 0.288 \\
\hline & $\mathrm{C}$ & 4 & 0.2195 & 0.000 \\
\hline $2 \mathrm{C}=\mathrm{C}$ & $\mathrm{CH}=\mathrm{CH}$ & 6 & 1.1167 & 0.867 \\
\hline $3 \mathrm{ACH}$ & $\mathrm{ACH}$ & 10 & 0.5313 & 0.400 \\
\hline $4 \mathrm{ACCH}_{2}$ & $\mathrm{ACCH}_{3}$ & 12 & 1.2663 & 0.968 \\
\hline $5 \mathrm{OH}$ & $\mathrm{OH}$ & 15 & 1.0000 & 1.200 \\
\hline $9 \mathrm{CH}_{2} \mathrm{CO}$ & $\mathrm{CH}_{2} \mathrm{CO}$ & 20 & 1.4457 & 1.180 \\
\hline \multirow[t]{2}{*}{$13 \mathrm{CH}_{2} \mathrm{O}$} & СH2O & 26 & 0.9183 & 0.780 \\
\hline & $\mathrm{CH}-\mathrm{O}$ & 27 & 0.6908 & 0.468 \\
\hline
\end{tabular}
group volume and group surface area parameters $\left(R_{k}\right.$ and $Q_{k}$ in table 2$)$.

Table 2 Group volume and surfaces area parameters (Wallas, 1984)
Parameter $v_{k}^{(i)}$ is the number of groups of type $k$ in molecule $i$. The last term in equation (1) is the residual activity coefficient due to interaction among groups. The group residual activity coefficient, $\Gamma_{i}^{(\mathrm{m})}$ is calculated using the following equations.

$$
\begin{aligned}
& \ln \Gamma_{k}=M_{k} Q_{k}^{\prime}\left[1-\ln \left(\sum_{m} \theta_{m}^{\prime} \Psi_{m k}\right)-\right. \\
& \left.\sum_{m}\left(\theta_{m}^{\theta_{m}^{\prime}} \Psi_{k m} /_{\theta_{m}^{\prime} \Psi_{n m}^{\prime}}\right)\right]
\end{aligned}
$$

where

$$
\begin{aligned}
& \theta_{\mathrm{m}}^{\prime}=\frac{\mathrm{Q}_{\mathrm{m}}^{\prime} \mathrm{W}_{\mathrm{m}}}{\sum_{\mathrm{n}} \mathrm{Q}_{\mathrm{n}}^{\prime} \mathrm{W}_{\mathrm{n}}} \\
& Q_{m}^{\prime}=\frac{Q_{k}}{M_{k}} \\
& \text { and } \\
& \Psi_{j k}=\exp \left(-\frac{a_{j k}}{T}\right)
\end{aligned}
$$

The group area parameter per gram $Q_{k}^{\prime}$ is defined by $Q_{k} / M_{k}$ and $W_{m}$ is the weight fraction of group $m$. The group-interaction parameters $a_{m n}$ and $a_{n m}$ (having units of degrees Kelvin) are factors for temperature dependency of interaction (table 3). While the group residual activity coefficient of group $\mathrm{k} \Gamma_{k}^{(i)}$ in equation (9) is a solution containing only molecules of type $i$.

The reduced volume in equation (10) are given by

$$
\begin{aligned}
& \bar{v}_{1}=\frac{v_{1}}{15.17 b r_{1}^{\prime}} \\
& \bar{v}_{2}=\frac{v_{2}}{15.17 b r_{2}^{\prime}}
\end{aligned}
$$

with $v_{1}$ and $v_{2}$ are, the volume per gram of tar model and that of solvent when equilibrium condition. In the equations (17) and (18), the charasteristic parameters are usually: $b=$ 1.32 for alkanes and 1.18 for water as solvents. The value of $\mathrm{b}$ is 1.4 for various organic compounds as solvent and $z=10$ (Stelmachowski \& Ledakowicz, 1993).

Table 3 The group-interaction parameters $a_{m n}$ and $a_{n m}(\mathrm{~K})$

\begin{tabular}{crrrrrrrr}
\hline $\mathbf{m} \backslash \mathbf{n}$ & \multicolumn{1}{c}{$\mathbf{1}$} & \multicolumn{1}{c}{$\mathbf{2}$} & \multicolumn{1}{c}{$\mathbf{3}$} & \multicolumn{1}{c}{$\mathbf{4}$} & $\mathbf{5}$ & $\mathbf{6}$ & $\mathbf{7}$ & $\mathbf{9}$ \\
\hline $\mathbf{1}$ & 0.00 & -200.00 & 61.13 & 76.50 & 986.5 & 697.2 & 1318 & 476.40 \\
$\mathbf{2}$ & 2520.00 & 0.00 & 340.70 & 4102.00 & 693.9 & 1509 & 634.2 & 524.50 \\
$\mathbf{3}$ & -11.20 & -94.78 & 0.00 & 167.00 & 636.1 & 637.3 & 903.8 & 25.77 \\
$\mathbf{4}$ & -69.70 & -269.70 & -146.80 & 0.00 & 803.2 & 603.2 & 5695 & -52.10 \\
$\mathbf{5}$ & 156.40 & 8694.00 & 89.60 & 25.82 & 0.0 & -137.1 & 353.3 & 84.00 \\
$\mathbf{6}$ & 16.51 & -52.39 & -50.00 & -44.50 & 249.1 & 0.0 & -181.0 & 23.39 \\
$\mathbf{7}$ & 300.00 & 692.70 & 362.30 & 377.60 & -229.1 & 289.6 & 0.0 & -195.40 \\
$\mathbf{9}$ & 26.76 & -82.92 & 140.10 & 365.80 & 164.5 & 108.7 & 472.5 & 0.00 \\
\hline
\end{tabular}




\section{Pseudo-Component}

Vegetable oils are essentially mixtures of saturated and unsaturated triacylglycerides (TAGs). It is difficult to know the exact distribution of the fatty acid chains in vegetable oils. One possible solution to the problem is representing the oil as a mixture of simple TAGs (tripalmitin, triolein, etc.) in accordance with the fatty acid composition of the natural oil. In this this work, we used another alternative by means of representing the oil by a single pseudocomponent having the same molecular weight and degree of unsaturation to the original oil.

In this work, the natural oil is represented by a single pseudotriacylglyceride with the following molecular structure (Espinosa et al., 2002):

$$
\left[\left(\mathrm{CH}_{2} \mathrm{COO}\right)_{2} \mathrm{CHCOO}\right](\mathrm{CH}=\mathrm{CH})_{\mathrm{m}}\left(\mathrm{CH}_{2}\right)_{\mathrm{n}}\left(\mathrm{CH}_{3}\right)_{3}
$$

The term in the square brackets represents the triglyceride functional group. The values of $m$ and $n$ reproduce molecular weight and degree of unsaturation of the natural oil, and are calculated from the fatty acid composition of the oil, as shown in table 4.

The values of $n$ and $m$ in the pseudotriacylglyceride, which represents the natural sunflower oil and palm oil, are calculated as follows:

$$
\begin{aligned}
& n=\sum_{i=1}^{N} n_{i} x_{i} \\
& m=\sum_{i=1}^{N} m_{i} x_{i}
\end{aligned}
$$

where $N$ is the number of fatty acids present in the natural oil and $i$ is the fatty acid molecule.

\section{Calculation}

When the UNIFAC-FV model is applied

to natural fatty oils, it is necessary to calculate the group composition of the oil from information on its fatty acid composition. In summary, the calculation to estimate Henry's constant are follows equation (10) until equation (18).

\section{Result and Discussion}

Henry's constant from experimental data about gas concentration of tar model at inlet and outlet of the buble column is given (Fig.1). Fig. 1 shows the variation of the outlet toluene concentration in the gas phase using palm oil as the solvent phase. The solvent was gradually loaded with toluene until its saturation, obtained when the outlet concentration reached the inlet value. At this moment, equilibrium between inlet gas and bulk liquid phase was achieved and Henry's constant can be calculated. Saturation concentrations values are reported in table 5 .

Based on our experimental data, the values of the Henry's constant for each couple toluene/solvent are reported in table 6. The lower lower weight-fraction Henry's constant is, the more important the tar model solubility in the solvent.

A recapitulative of experimental, literature and prediction by UNIFAC-FV given on table 6, lubrication oil appears clearly to be better absorbent than others as it has high capacity of toluene absorption. System of toluene-water of experimental result compared with literature data, there are great deviations.

Predicted Henry's constant generally the VLE for the oil solution systems at infinite dilution is very difficult. The weight-fraction Henry's constant of systems were predicted by fixing $C_{1}=1$ (equation (9)) and $b=1.18$, 1.32 and 1.4 for water (equations (17) and (18)), alkanes and different organic compounds as solvent (Iwai et al., 1981), respectively. Molecule structure of sunflower

Table 4. Typical fatty acid composition

\begin{tabular}{lcccc}
\hline & \multicolumn{2}{c}{$\boldsymbol{X}_{\boldsymbol{i}}$} & & \\
\cline { 2 - 3 } Fatty acid & sunflower oil $^{*}$ & palm oil** & $\boldsymbol{n}_{\boldsymbol{i}}$ & $\boldsymbol{m}_{\boldsymbol{i}}$ \\
\hline Palmitic & 0.0670 & 0.4806 & 42 & 0 \\
Stearic & 0.0334 & 0.0430 & 48 & 0 \\
Oleic & 0.2583 & 0.3781 & 42 & 3 \\
Linoleic & 0.6391 & 0.0983 & 36 & 6 \\
Linolenic & 0.0022 & 0 & 30 & 9 \\
\hline
\end{tabular}

* Espinosa et al., 2002

** Odem, 2002 


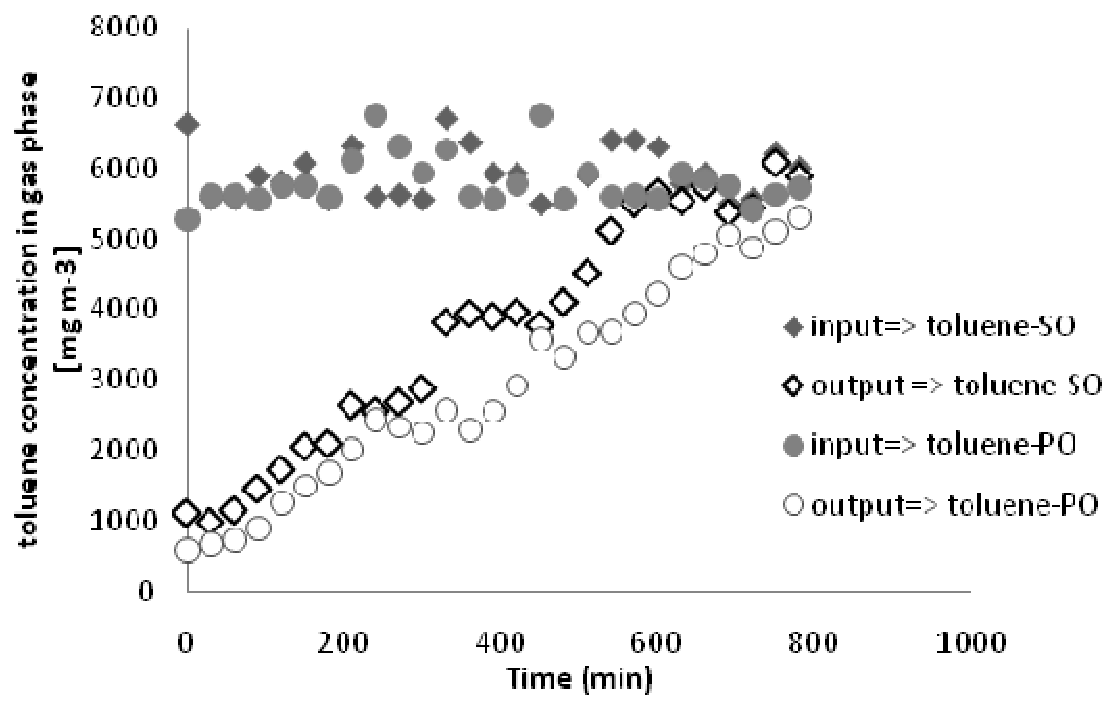

Figure 1. Inlet and outlet toluene in gas phase versus time (an example)

Table 5. Saturation concentrations $C_{L}$ for different concentrations in air

\begin{tabular}{clcccc}
\hline & System & \multicolumn{2}{c}{ 303 K } & \multicolumn{2}{c}{ 333 K } \\
\hline \multirow{4}{*}{ Toluene } & \multicolumn{1}{c}{$(2)$} & $C_{G, \text { out }}\left(\mathrm{mg} \mathrm{m}^{-3}\right)$ & $C_{L}\left(\mathrm{~g} \mathrm{~L}^{-1}\right)$ & $C_{G, \text { out }}\left(\mathrm{mg} \mathrm{m}^{-3}\right)$ & $C_{L}\left(\mathrm{~g} \mathrm{~L}^{-1}\right)$ \\
& Sunflower Oil & 6786 & 1.0454 & 6023 & 0.951 \\
& Palm Oil & 6713 & 1.2570 & 6580 & 1.1032 \\
& Lubrication Oil & 6709 & 1.3899 & 6342 & 1.2731 \\
& water & 2830 & 0.0056 & 6225 & 0.0448 \\
\hline
\end{tabular}

Table 6. Weight-fraction Henry's constant from experimental

\begin{tabular}{|c|c|c|c|c|c|c|}
\hline \multicolumn{2}{|r|}{ System } & \multirow[t]{2}{*}{$\begin{array}{c}\mathrm{Q}(\mathrm{mL} \\
\left.\text { menit }^{-1}\right)\end{array}$} & \multicolumn{2}{|c|}{$\begin{array}{c}\text { (atm } / \text { mass } \\
\text { frac.) }\end{array}$} & \multicolumn{2}{|c|}{$\left(\mathrm{atm} \cdot \mathrm{m}^{3} / \mathrm{mol}\right)$} \\
\hline (1) & $(2)$ & & $30^{\circ} \mathrm{C}$ & $60^{\circ} \mathrm{C}$ & $30^{\circ} \mathrm{C}$ & $60^{\circ} \mathrm{C}$ \\
\hline \multirow[b]{6}{*}{ Toluene } & \multirow{2}{*}{ Sun flower oil } & 13,6 & 1,9 & 2,4 & $2,014 \times 10^{-4}$ & $2,690 \times 10^{-4}$ \\
\hline & & 27,6 & 1,2 & 1,4 & $1,272 \times 10^{-4}$ & $1,569 \times 10^{-4}$ \\
\hline & \multirow{2}{*}{ Palm oil } & 13,6 & 1,7 & 1,8 & $1,757 \times 10^{-4}$ & $1,901 \times 10^{-4}$ \\
\hline & & 27,6 & 1,0 & 1,2 & $1,034 \times 10^{-4}$ & $1,267 \times 10^{-4}$ \\
\hline & \multirow{2}{*}{ Lubricant oil } & 13,6 & 1,6 & 1,6 & $1,575 \times 10^{-4}$ & $1,774 \times 10^{-4}$ \\
\hline & & 27,6 & 0,8 & 0,9 & $0,787 \times 10^{-4}$ & $0,998 \times 10^{-4}$ \\
\hline & \multirow{2}{*}{ Water } & 13,6 & 39,5 & 42,8 & $36,486 \times 10^{-4}$ & $40,057 \times 10^{-4}$ \\
\hline & & 27,6 & 26,6 & 35,3 & $24,570 \times 10^{-4}$ & $33,038 \times 10^{-4}$ \\
\hline
\end{tabular}

oil and palm oil representated by a single pseudo-triacylglyseride with the following molecule structure:

Sunflower oil:

$\left[\left(\mathrm{CH}_{2} \mathrm{COO}\right)_{2} \mathrm{CHCOO}\right](\mathrm{CH}=\mathrm{CH})_{5}\left(\mathrm{CH}_{2}\right)_{38}\left(\mathrm{CH}_{3}\right)_{3}$

Palm Oil:

$\left[\left(\mathrm{CH}_{2} \mathrm{COO}\right)_{2} \mathrm{CHCOO}\right](\mathrm{CH}=\mathrm{CH})_{2}\left(\mathrm{CH}_{2}\right)_{42}\left(\mathrm{CH}_{3}\right)_{3}$
Palmitodiolein:

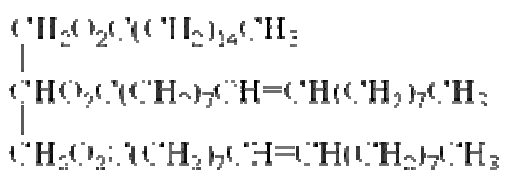

Eicosan: $\mathrm{CH}_{3}-18\left(\mathrm{CH}_{2}\right)-\mathrm{CH}_{3}$

For molecule structure of palm oil can be representated by palmitodiolein and lubrication oil by eicosan (Wibowo, 2008). 


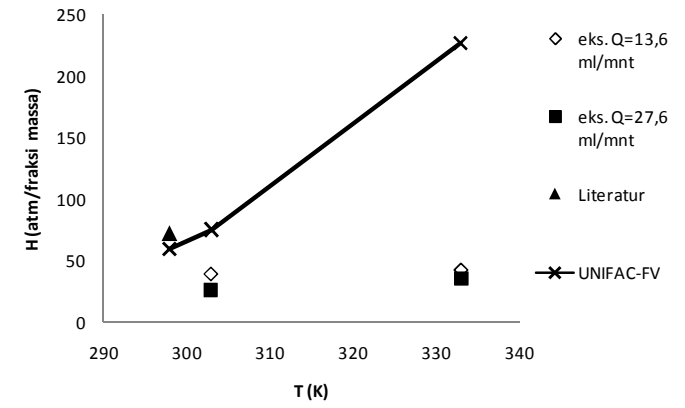

(a) toluene-water

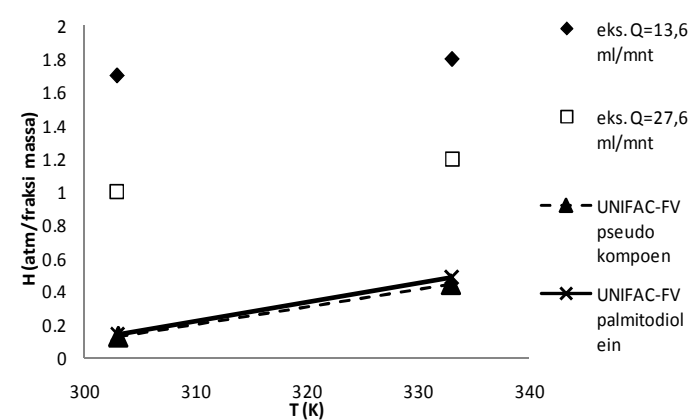

(c) toluene-palm oil

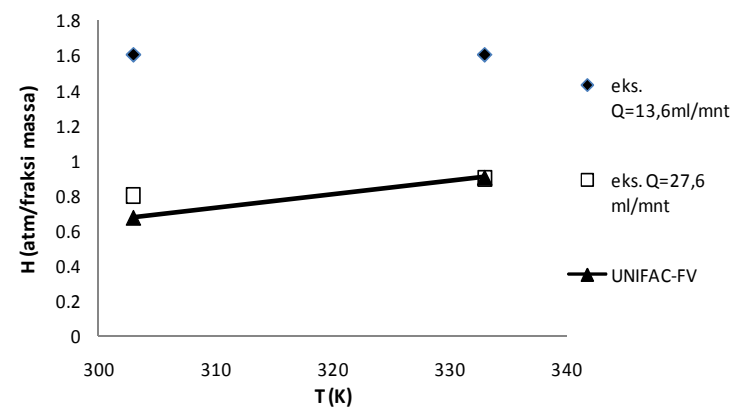

(b) toluene-lubricant oil

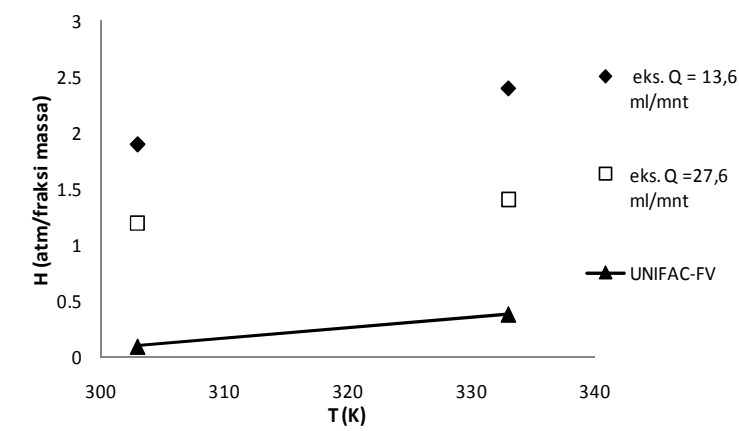

(d) toluene-sunflower oil

Figure 2 Henry's constants mass fraction for system: (a) Toluene-water; (b) toluenelubricant oil (c) toluene-palm oil (d) toluene-sunflower oil

Table 7. Weight-fraction Henry's constant from prediction with $C_{1}=1 ; b=1.18,1.32$ and 1.4 for water, alkanes and different organic compounds as solvent, respectively.

\begin{tabular}{|c|c|c|c|c|c|c|}
\hline \multicolumn{2}{|r|}{ Sistem } & \multicolumn{3}{|c|}{$\begin{array}{c}\text { H UNIFAC-FV } \\
\text { (atm/mass frac.) }\end{array}$} & \multirow{2}{*}{$\begin{array}{c}\begin{array}{c}\text { H literature } \\
\text { (atm/mass frac.) }\end{array} \\
25{ }^{\circ} \mathrm{C}\end{array}$} & \multirow[t]{2}{*}{ error } \\
\hline (1) & $(2)$ & $25^{\circ} \mathrm{C}$ & $30^{\circ} \mathrm{C}$ & $60^{\circ} \mathrm{C}$ & & \\
\hline \multirow{8}{*}{ Toluene } & $\begin{array}{l}\text { Sun flower oil } \\
\text { (pseudo-triacylglyseride) }\end{array}$ & - & 0,095 & 0,379 & - & $73 \%-92 \%$ \\
\hline & $\begin{array}{l}\text { Palm oil } \\
\text { (pseudo-triacylglyseride) }\end{array}$ & - & 0,130 & 0,444 & - & $63 \%-87 \%$ \\
\hline & $\begin{array}{l}\text { Palm oil } \\
\text { (palmitodiolein) }\end{array}$ & - & 0,145 & 0,484 & - & $60 \%-85 \%$ \\
\hline & $\begin{array}{l}\text { Lubricant oil } \\
\text { (eicosan) }\end{array}$ & - & 0,672 & 0,903 & - & $0,3 \%-16 \%$ \\
\hline & Water & 59,200 & 74,830 & 227 & $60,890 *$ & $2,77 \%$ \\
\hline & hexadecane & 0,102 & - & - & $0,189 *$ & $46 \%$ \\
\hline & Oley alcohol (70\%) & 0,326 & - & - & $0,132 *$ & \\
\hline & DEHA & 0,182 & - & - & $0,079 *$ & $130 \%$ \\
\hline
\end{tabular}


Table 8. External degree of freedom $\left(C_{1}\right)$ and $b$ parameter of systems toluene(1)-solvent(2) with average error $0,001 \%$

\begin{tabular}{|c|c|c|c|c|c|c|c|c|c|}
\hline \multirow{2}{*}{\multicolumn{2}{|c|}{ System }} & \multicolumn{6}{|c|}{ New parameter } & \multicolumn{2}{|c|}{ Old parameter } \\
\hline & & \multicolumn{3}{|c|}{$\mathrm{C}_{1}$} & \multicolumn{3}{|c|}{$b$} & \multirow[t]{2}{*}{$\mathbf{C}_{1}$} & \multirow[t]{2}{*}{$b$} \\
\hline (1) & $(2)$ & $25^{\circ} \mathrm{C}$ & $30^{\circ} \mathrm{C}$ & $60^{\circ} \mathrm{C}$ & $25^{\circ} \mathrm{C}$ & $30^{\circ} \mathrm{C}$ & $60^{\circ} \mathrm{C}$ & & \\
\hline \multirow[t]{7}{*}{ Toluene } & $\begin{array}{l}\text { Sunflower oil } \\
\text { (pseudo- } \\
\text { triacylglyseride) }\end{array}$ & - & 2,003 & 2,016 & - & 1,929 & 1,956 & 1,000 & 1,400 \\
\hline & $\begin{array}{l}\text { Palm oil } \\
\text { (pseudo- } \\
\text { triacylglyseride) }\end{array}$ & - & 1,006 & 1,029 & - & 1,968 & 2,060 & 1,000 & 1,400 \\
\hline & $\begin{array}{l}\text { Palm oil } \\
\text { (palmitodiolein) }\end{array}$ & - & 1,014 & 1,040 & - & 1,974 & 2,071 & 1,000 & 1,400 \\
\hline & Lubricant oil (eicosan) & - & 1,298 & 1,311 & - & 1,315 & 1,408 & 1,000 & 1,400 \\
\hline & Water & 1,005 & 0,689 & 11,708 & 1,181 & 0,133 & 0,216 & 1,000 & 1,180 \\
\hline & Hexadecane & 1,047 & - & - & 1,636 & - & - & 1,000 & 1,320 \\
\hline & oley alcohol $(70 \%)$ & 0,999 & - & - & 1,259 & - & - & 1,000 & 1,400 \\
\hline
\end{tabular}

The results of prediction by UNIFACFV were tabled on Figure 3 and table 7 , compared with experimental values (table 6) has great deviation. To obtain better results, it requires the parameters of UNIFAC-FV model in order to correlate with the experimental data. Therefore, to determine the new parameters $C_{1}$ of equation (9) and $b$ of equations (17) and (18) was carried out by minimizing the sum of squares between experimental data of Henry's constant and those calculated by the UNIFAC-FV model. The new parameters were given in table 8 .

\section{Conclusion}

This paper aimed to review tar model absorption knowledge, and by a methodic way and a gas cleaning of gasification technology purpose to determine a absoptionn capacity several types of oil as absorbent. From experimental data, lubrication oil as the most attractive absorbent. To obtain better result of prediction by UNIFAC-FV, the parameter $\mathrm{C}_{1}$ and $b$ for oil systems could be adjusted by minimizing the sum of squares between experimental data and those calculated by UNIFAC-FV.

\section{Acknowledgement}

This work was accomplished with the financial support of Tanoto Foundation. This work conducted at the ITB with Prof. Dr. Herri Susanto as supervisor. This paper was presented at $16^{\text {th }}$ RSCE in Manila, Philippine, 2009.

\section{Notation}

$C_{\mathrm{G}, \mathrm{i}}, C_{\mathrm{G}, \mathrm{o}}$ inlet and outlet gas concentration $\left(\mathrm{mg} \mathrm{m}^{-3}\right)$

$C_{L} \quad$ solute concentration in liquid phase (mg ms)

$f_{s} \quad$ fugacity of solute (atm)

$f_{s}^{o} \quad$ fugacity of pure liquid of solute (atm)

$\mathrm{H} \quad$ Henry's constant weight fraction (atm/weight frac.)

1/H dimensionless Henry's constant (-)

$M \quad$ molecular weight

$Q_{G} \quad$ gas flow rate $\left(\mathrm{mL} \mathrm{min}^{-1}\right)$

$S \quad$ solute

$V_{\mathrm{L}} \quad$ absorbent volume $\left(\mathrm{m}^{3}\right)$

$w_{s} \quad$ weight fraction of solute (-)

$x_{S} \quad$ molar fraction of solute in liquid phase (-)

$y_{s} \quad$ mole fraction of solute in gas phase

$\mu \quad$ viscosity $(\mathrm{cP})$

$\varphi_{s}^{o} \quad$ fugacity coefficient of solute

$\gamma_{s}^{\infty} \quad$ activity coefficient of solute at infinite dilution

\section{References}

Espinosa, S.; Fornari, T.; Bottini, S.B.; Brignole, E.A., Phase equilibria in mixtures of fatty oils and derivatives with near critical fluids using the GC-EOS model, The Journal of Supercritical Fluids, 2002, Vol. 23(2), 91-102.

Hasler, P.; Nussbaumer, Th., Gas cleaning IC engine applications from fixed bed biomass gasification, Biomass and Bioenergy, 1999, Vol. 16(6), 385-395. 
Iwai, Y.; Anai, Y.; Arai, Y., Prediction of solubilities for volatile hydrocarbons in lowdensity polyethylene using UNIFAC-FV model, Polymer Engineering \& Science, 1981, Vol. 21(15), 1015-1018.

Odem, D.0., Palm oil: Biochemical, physiological, nutritional, hematological, and toxilogical aspect: A review, Plant Foods for Human Nutrition, 2002, Vol. 57(3-4), 319341.

Stelmachowski, M.; Ledakowicz, S., Prediction of Henry's constants by the UNIFAC-FV model for hydrocarbon gases and vapors in highboiling hydrocarbon solvents, Fluid Phase Equilibria, 1993, Vol. 90(2), 205-217.
Vuong, M.-D.; Couvert, A.; Couriol, C.; Amrane, A.; Le Cloirec, P.; Renner, C., Determination of the Henry's constant and mass transfer rate of VOCs in solvents, Chemical Engineering Journal, 2009, Vol. 150(2-3), 426-430.

Wibowo, W.A., Preliminary study of tar removal from producer gas by oil absorption, Master Thesis, Chemical Engineering Study Program, Faculty of Industrial Technology, Institut Teknologi Bandung, 2008.

Wallas, S.M., Phase Equilibria in Chemical Engineering, Butterworth Publishers, 1984. 